\title{
Antifouling properties of chitosan coatings on plastic substrates
}

${ }^{1,2}$ Laila Al-Naamani, ${ }^{3}$ Thirumahal Muthukrishnan, ${ }^{4}$ Joydeep Dutta, ${ }^{5}$ Sergey Dobretsov

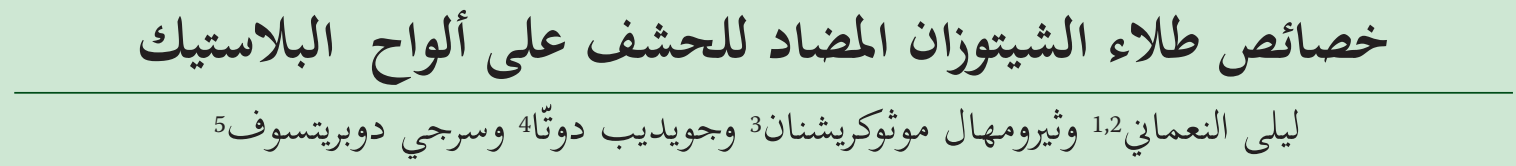

AbStract. In the current study, chitosan coatings were fabricated on plastic substrata and investigated for their antifouling activities. Scanning Electron Microscopy (SEM) and water contact angle measurement (WCA) of the fabricated chitosan films showed smooth and hydrophilic surface with WCA below $60^{\circ} \mathrm{C}$. In the first experiment, chitosan coating on plastic substrate showed $88 \%$ reduction in settlement of bryozoan Bugula neritina larvae compared to the control after 3 hours incubation at dark conditions with no larval mortality. In the second experiment, the antimicrobial activity of chitosan was evaluated by coating plastic panels with the prepared chitosan solution and immersing the coated samples in seawater at controlled environmental conditions for two weeks. Biofilms scraped from immersed chitosan coated panels showed no bacteria after 1 week of immersion. After the second week of immersion, less than 1500 bacteria $/ \mathrm{mm}^{2}$ were observed on the chitosan-coated panels compared to more than $10^{5}$ bacteria/ $\mathrm{mm}$ on uncoated ones. Thus, this study proved the efficiency of chitosan coatings against micro- and macro-fouling.

KEYwORDS: Chitosan; anti-larval activity; antifouling activity; bryozoan; biofilms.

$$
\begin{aligned}
& \text { المستخلص:في الدراسة الحالية، تم طلاء مادة الكيتوزان على ألواح بلاستيكية وبحث إمكانية استخدامها كمادة مضادة للترسبات الحيوية البحرية. }
\end{aligned}
$$

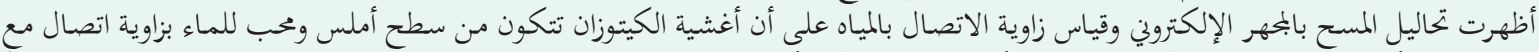

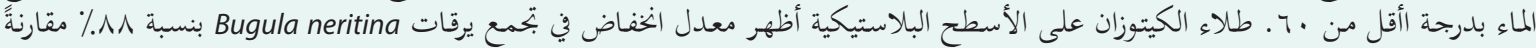

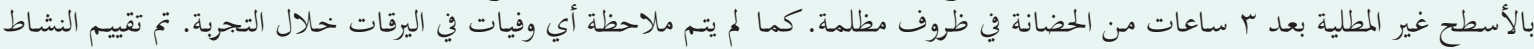

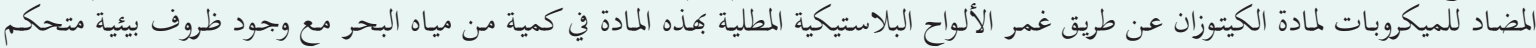

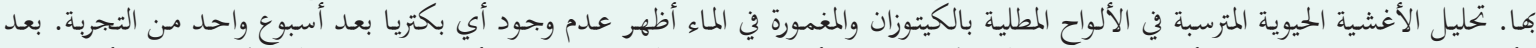

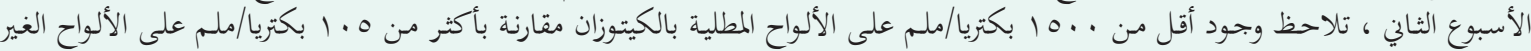

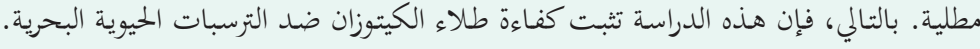

$$
\begin{aligned}
& \text { الكلمات المفتاحية: التراكم الحيوي على الأسطح المغمورة، }
\end{aligned}
$$

\section{Introduction}

$\mathrm{N}$ atural and biodegradable biopolymers are currently receiving great interest to be used as alternative to petroleum polymers in terms of raw material supply and waste product reduction (Leceta et al. 2013). Chitosan is a biocompatible, biodegradable and bioactive biopolymer, which can be used in diverse industrial applications (Chatelet et al. 2001). It exhibits numerous interesting physicochemical and biological properties with various applications in water treatment, agriculture, biomedicine, food industry, and marine antifouling management (Cestari et al 2007; El-Sawy et al. 2010; Ramya et al. 2012; Luo \& Wang 2013; Cai et al. 2016; Al-Naamani et al. 2017).

Chitosan possesses antimicrobial properties against

1,2 Laila Al-Naamani $(\square)$ lnaamani@hotmail.com ${ }^{1}$ Department of Marine Science and Fisheries' Sultan Qaboos University, 123 Al-Khoud, Oman. ${ }^{2}$ Ministry of Municipalities and Water Resources, Muscat, Sultanate of Oman. ${ }^{3}$ Department of Biology, Sultan Qaboos University, 123 Al-Khoud, Oman. ${ }^{4}$ Functional Materials Division, Materials and Nano Physics Department, ICT School, KTH Royal Institute of Technology, SE-164 40, Kista, Stockholm, Sweden. ${ }^{5}$ Center of Excellence in Marine Biotechnology, Sultan Qaboos University, 123 Al-Khoud, Oman. a number of bacteria, fungi and algae (Benhabiles et al. 2012; Lam \& Diep 2015; Park et al. 2016). Antimicrobial properties of chitosan are due to the positively charged $\mathrm{NH}^{2+}$ ions which interact with the negatively charged molecules in the microbial cell membranes leading to disruption of the cells (Coma et al. 2003; Alisashi \& Aïder 2012). The efficiency of the bactericidal effect of chitosan is dependent on various factors, such as microorganism strain or species, environmental conditions ( $\mathrm{pH}$, temperature), molecular weight and concentration of chitosan as well as its physical state (solution or film) (Kong et al. 2010; Leceta et al. 2013).

According to the field of application, chitosan can be modified to form powder, flakes, gel beads, fibres or membranes and several other forms (Wang \& Shen 2000; Pitakpoolsil \& Hunsom 2014; Zhang et al. 2015). Chitosan films or membranes have found their ways in various industrial applications such as water desalination, as coating for food applications, wound dressing, and tissue engineering (Goy 2009; Sudha et al. 2015). Films can be easily prepared by dissolving chitosan powder or flakes in diluted acid solutions like acetic acid, and then casting the resulting solution on a flat surface or 
dipping or coating of any substrate, and finally allowing them to dry (Krajewska 2005; Goy 2009).

Biofouling is the undesirable attachment and growth of micro- (bacteria and diatoms) and macro-fouling (bryozoans, barnacles, mussels, etc.) organisms on manmade installations (Wahl 1989). Maritime industries spent billions of US dollars to prevent and control biofouling. Current ways of controlling biofouling include the use of toxic antifouling coatings that kill organisms and pollute the environment (Hellio \& Yebra 2009). Thus, non-toxic antifouling solutions are urgently needed. Due to chitosan biodegradability, low toxicity to eukaryotes and environmental safety, chitosan films have been proposed as a green approach to prevent biofouling and as an alternative to toxic biocides (Pelletier et al. 2009). Chitosan was proven as a successful antifouling coating for membranes (Zhao et al. 2003; Zhou et al. 2010). A study by Yang et al. (2011) found that stainless steel functionalised with chitosan and hydroxyethylmethacrylate (HEMA) polymer reduced protein adsorption, bacterial adhesion, and exhibited antibacterial activity against $\mathrm{E}$. coli. Chitosan films in laboratory experiments inhibited growth of fouling microorganisms, such as Pseudomonas and Bacillus (Machul et al. 2015; Zhou et al. 2013). A two months field study in northern Canadian waters was conducted with chitosan-based coatings (Pelletier et al. 2009). While the results of the study demonstrated promising antibacterial activity, the coating did not have any activity against algae. In our previous study, chitosan-zinc oxide nanocomposite coatings prevented growth of fouling diatoms and marine bacteria in laboratory and mesocosm experiments (Al Naamani et al. 2017). At the same time, the antifouling effect of chitosan films on larval settlement of major fouling species, like the bryozoan Bugula neritina (Dahms et al. 2004), has not been investigated.

The aims of this study were to: 1) fabricate chitosan coatings and characterise their physical and chemical properties, and 2) determine antifouling activity of chitosan coatings against micro- and macro-fouling organisms in laboratory experiments.

\section{Materials and Methods}

\section{Preparation of chitosan solution}

Two and a half grams of commercial chitosan powder of medium molecular weight with $110 \mathrm{cps}$ viscosity and 95.6\% deacetylation (Tru-Nutra Nutraceuticals LLC, India) were mixed with a volume of $100 \mathrm{~mL}$ of $2 \%$ acetic acid (Sigma Aldrich, USA) to prepare $2.5 \%$ chitosan solution. The solution was kept under constant stirring for $24 \mathrm{~h}$ at $25^{\circ} \mathrm{C}$.

The viscous solution was coated on plastic substrates and allowed to dry for $24 \mathrm{~h}$ at $26^{\circ} \mathrm{C}$. The resulting coatings were characterized using FTIR spectrophotometery, scanning electron microscopy (SEM) and water contact angle. The chitosan coatings were analysed directly using FTIR spectroscopic equipment (PerkinElmer, USA, Frontier ${ }^{\mathrm{TM}}$ ), in a spectral range from 4000 to $400 \mathrm{~cm}^{-1}$ at a resolution of $4 \mathrm{~cm}^{-1}$. Surface morphologies of dry coatings were characterized using JEOL JSM-7200 (Japan) field emission scanning electron microscope (FESEM) working at $20 \mathrm{kV}$. The water contact angle (WCA) of coated substrates was measured using a Theta Lite Attension tensiometer (Biolin Scientific, Sweden) using a sessile drop technique to determine the films hydrophobicity (Al-Fori et al. 2014). A drop of $5 \mu \mathrm{L}$ water was placed in five different positions on each coating's surface. The right and left contact angles of each drop were measured and a mean water contact angle (WCA) was calculated from the resulting two values.

\section{Activity assessments of chitosan coatings on surfaces}

\section{Anti-larval activity assessment}

To determine the anti-larval activity of chitosan, the prepared chitosan solution in acetic acid was coated on plastic panels (low density polyethylene, size $1 \mathrm{~cm}^{2}$ ) and allowed to dry overnight. Three replicates of chitosan coated plastic panels were placed into a 24-well plate (Corning Costar, USA). Uncoated clean plastic panels were used as a control. Each well was filled with 1 $\mathrm{mL}$ seawater containing the bryozoan Bugula neritina larvae. Adult broodstocks of $B$. neritina were collected from pilings and floating rafts at Marina Bandar Rowdah. Larvae were obtained according to the method described by Bryan et al. (1997) and only newly (i.e., within $10 \mathrm{~min}$ ) released larvae were included in the bioassays.

Experiments were conducted under dark conditions by covering the 24-well plate with aluminium foil. In each well, the number of dead larvae, attached larvae and the total number of larvae were counted under a dissecting microscope (Zeiss, Germany, magnification $10 \mathrm{X})$ after $1 \mathrm{~h}, 2 \mathrm{~h}$ and $3 \mathrm{~h}$. The percentages of larval mortality and larval settlement were calculated as follows (equations 1 and 2).

$$
\begin{array}{ll}
\text { Larval mortality }(\%)=(\mathrm{NDL}) /(\mathrm{TL}) \times 100 & \text { Eq. }(1) \\
\text { Larval settlement }(\%)=(\mathrm{NSL}) /(\mathrm{TL}) \times 100 & \text { Eq. }(2)
\end{array}
$$

Where NDL is the number of dead larvae, TL is the total number of larvae and NSL is the number of settled larvae.

\section{Anti-microfouling activity}

To determine the antifouling activity of the chitosan in a small scale microcosm experiment, three different coatings were prepared: (a) 2.5\% chitosan solution, (b) commercial two component non-toxic paint (Hempadur 45182, Hempel, Denmark) mixed with $2.5 \%$ chitosan solution at a ratio of $1: 1$ (v:v), (c) commercial two component non-toxic paint (Hempadur 45182, Hempel, Denmark). Plastic panels (Acrylic, $7.5 \mathrm{~cm} \times 2.5 \mathrm{~cm}$ ) were cleaned and both sides of the panels then painted with 


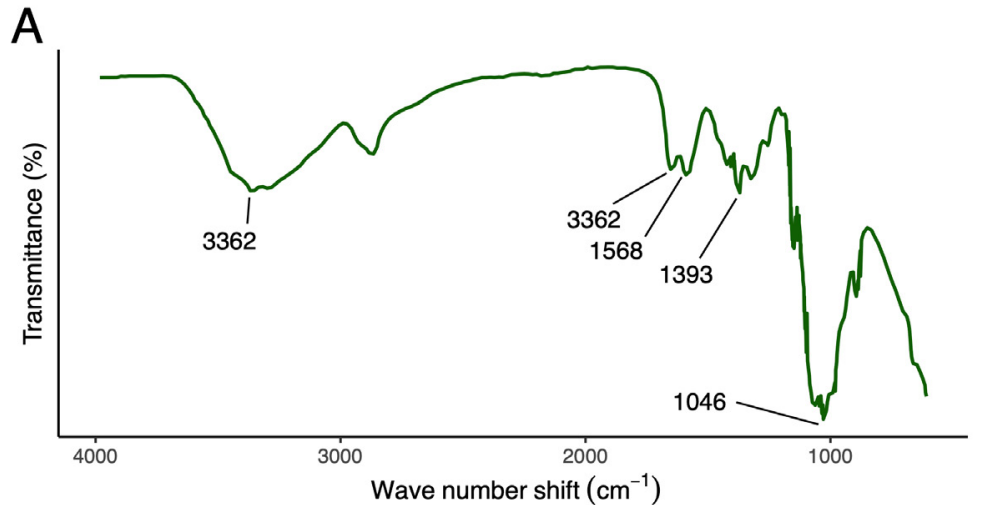

B

C
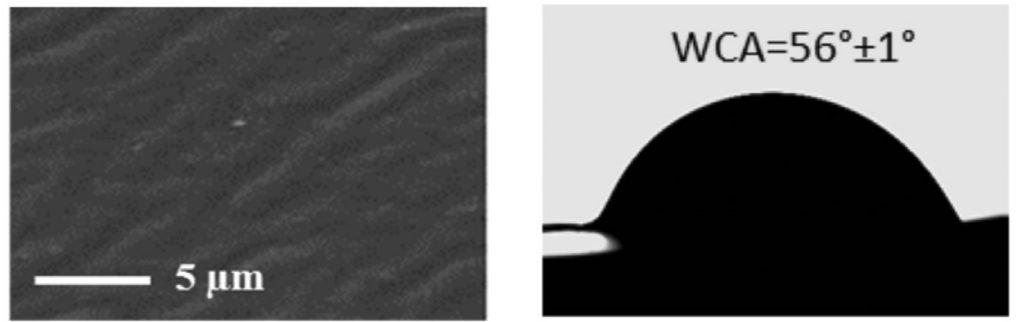

Figure 1. (A) FTIR spectra of chitosan coating on plastic panels using $2.5 \%$ chitosan dissolved in $2 \%$ acetic acid, (B) SEM image of the chitosan coating, $(C)$ Water control angle of the chitosan coating.

a brush with each of the coatings. The coatings were allowed to dry for 24 hours at room temperature. Uncoated clean plastic panels were used as a control. Each panel was immersed vertically in a separate beaker containing seawater. Beakers were incubated at $26^{\circ} \mathrm{C}$ for 2 weeks. Each treatment and the control were replicated three times. After 1 week and 2 weeks, panels were removed. Biofilms from the whole area of the panel were scraped from the surface into Eppendorf tubes using a sterile scalpel. The remaining traces of the biofilm were rinsed with distilled water into the tube. Ten $\mu \mathrm{L}$ of the resulting biofilm suspension from each tube were added on a microscope glass slide and mixed with $10 \mu \mathrm{L}$ of SYBR Green 1 stain (SIGMA, Aldrich, USA) and incubated for $10 \mathrm{~min}$. Finally, slides were analysed by an epifluorescence microscope. The number of bacteria in 20 randomly selected fields of view (Muthukrishnan et al. 2017) was counted and the total abundance of bacteria within $1 \mathrm{~mm}^{2}$ was calculated.

\section{Results and Discussion}

\section{Chitosan film characterization}

The FTIR spectra of chitosan coatings (Figure 1a) showed a characteristic peak at $3362 \mathrm{~cm}^{-1}$ for $\mathrm{N}-\mathrm{H}$ and $\mathrm{O}-\mathrm{H}$ stretching. Peaks corresponding to amide I and amide II were observed at $1662 \mathrm{~cm}^{-1}$ and $1598 \mathrm{~cm}^{-1}$, respectively. The characteristic peak at 1046 is attributed to $\mathrm{C}-\mathrm{O}$ stretching. The main absorption peaks of chitosan films have been reported to be at $1650 \mathrm{~cm}^{-1}$, attributed to $\mathrm{C}=\mathrm{O}$ stretching (amide I), $1558 \mathrm{~cm}^{-1}$ attributed to $\mathrm{N}-\mathrm{H}$ bending (amide II) and $1382 \mathrm{~cm}^{-1}$ attributed to C-N stretching (amide III). The broad bands above $3000 \mathrm{~cm}^{-1}$ assigned to $\mathrm{O}-\mathrm{H}$ and $\mathrm{N}-\mathrm{H}$ bonds while absorption peaks at $1050 \mathrm{~cm}^{-1}$ were attributed to $\mathrm{C}-\mathrm{O}$ stretching (Fernandez-Saiz et al. 2007; Leceta et al. 2013). The SEM images and WCA results showed a smooth and hydrophilic surface of chitosan coatings as shown in Figures 1b and 1c.

\section{Anti-larval activity of chitosan coating}

Bugula neritina is a common fouling marine bryozoan with a short pelagic larval stage which can be found in warm temperate and subtropical waters worldwide (Ryland et al. 2011; Linneman et al. 2014). Bugula larvae have barrel-shaped bodies with their surfaces mostly covered with cilia that are referred to as a ciliated corona. Those cilia assist the larvae in swimming (Price et al. 2017).

The effect of chitosan coatings on the mortality and settlement of the bryozoan Bugula neritina larvae after 3 hours incubation in dark conditions is shown in Table Table 1. Effect of chitosan coating on Bugula neritina larval mortality and settlement after 1, 2, and 3 hours of incubation at dark conditions. Control is seawater.

\begin{tabular}{ccccccc|} 
& \multicolumn{3}{c}{ \% Larval mortality } & \multicolumn{3}{c|}{ \% Larval settlement } \\
& 1h & $2 \mathrm{~h}$ & $3 \mathrm{~h}$ & $1 \mathrm{~h}$ & $2 \mathrm{~h}$ & $3 \mathrm{~h}$ \\
\hline Control & 0 & 0 & 0 & $100 \pm 0$ & $100 \pm 0$ & $100 \pm 0$ \\
\hline Chitosan & 0 & 0 & 0 & $12 \pm 6.3$ & $12 \pm 6.3$ & $12 \pm 6.3$ \\
\hline
\end{tabular}


1. Results showed no larval mortality during the whole experiment. A 10-fold significant decrease in settlement of the larvae on chitosan films in comparison with the control was observed (Table 1). All larvae settled in the control and no changes in the settlement rate were observed during the incubation period. Overall, there was no difference in the larval settlement between $1 \mathrm{~h}, 2 \mathrm{~h}$ and $3 \mathrm{~h}$ on chitosan film and the control. This can be explained by the fact that $B$. neritina has fast settling larvae that attach to the substratum within one hour (Bryan et al. 1997).

To our knowledge, this is the first study stating the effect of chitosan on the mortality and settlement of $B$. neritina larvae. Previously, Rasmussen et al. (2002) investigated the settlement of cyprids of Balanus amphitrite on chitosan gel crosslinked with glutaraldehyde. The authors observed a reduction in larval settlement to $35 \%$ when chitosan concentration was $2 \%$. The settlement of $B$. neritina larvae on the surface of $8 \times 10 \mathrm{~cm}$ plastic panels coated with low density polyethylene (LDPE), polypropylene (PP), polyvinyl chloride (PVC) and high density polyethylene (HDPE) was studied by $\mathrm{Li}$ et al. (2016). The authors reported higher larval settlement on the surface of panels coated with LDPE, PP, and PVC, compared to HDPE and glass panels after immersion in water for 4 days. The influences of organic films, such as chitosan, PP, PVC, etc., on larval settlement is not yet clear. It was suggested that physical, chemical and biological factors of the substratum, such as roughness, chemical properties of the substratum, presence of biofilms and other species, could affect larval settlement in the field (Clare et al. 1992; Faimali et al. 2004; Dobretsov et al. 2006; Qian et al. 2007; Li et al. 2016).

\section{Antimicrobial experiment}

The experiment showed that the lowest bacterial abundances were found on chitosan coatings; no bacteria af-

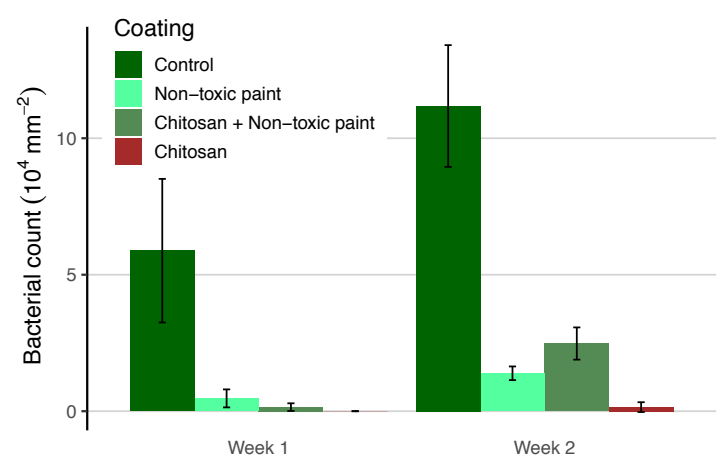

Figure 2. Bacterial abundances on plastic panels coated with commercial non-toxic paint, commercial non-toxic paint mixed with $2.5 \%$ chitosan coating in ratio (1:1) and $2.5 \%$ chitosan coating. The control represents an uncoated panel.

ter 1 week and $<1500$ bacteria/ $\mathrm{mm}^{2}$ after 2 weeks of immersion were observed (Fig. 2). The highest densities of bacteria were found on the control substrata after 1 and 2 weeks of the experiment. The non-toxic antifouling paint was more effective than the mixture of non-toxic paint and chitosan (Fig. 2). Only a few algal cells were observed in the control samples. Comparatively, higher numbers of algal cells were observed on samples coated with non-toxic paint. However, no algal cells were observed on both the panels coated with a mixture of non-toxic paint and chitosan solution and that of only chitosan solution.

In the marine environment, the antifouling activity of chitosan was directly evaluated by Pelletier et al. (2009). They demonstrated antibacterial activity of $20 \%$ chitosan coating after 14 days of immersion in the sea, while $5 \%$ chitosan coating did not have any antifouling activity. Antibacterial activity of chitosan with concentration less that $2 \%$ chitosan was observed against $\mathrm{Ba}$ -

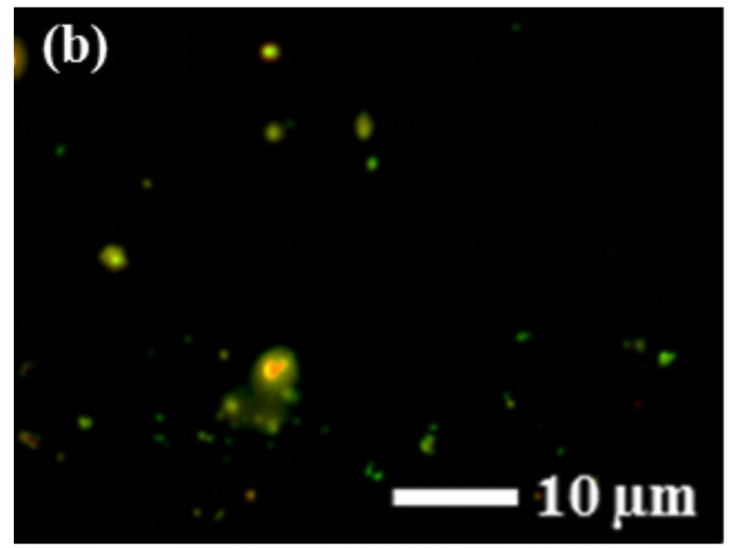

Figure 3. Bacterial cells as observed by epifluorescence microscopy at 1000X magnification in (a) biofilms scraped from the uncoated control plastic panels, and (b) biofilm scraped from panels coated with a mixture of chitosan and non-toxic paint. Cells were stained with CYBR Green I dye. 
cillus sp., Vibrio and Pseudomonas sp., which are known to be involved in the biofouling process (Sekiguchi et al. 1994; Jumaa et al. 2002; No et al. 2002; Rasmussen \& Østgaard 2003). It is well known that the cationic amine group in the chitosan molecule has a major role in its antimicrobial activity, as it forms electrostatic interactions with anionic group on the cell membrane of bacterial cells, which eventually lead to cell death (Rabea et al. 2003; Alisashi \& Aïder 2012). However, in our experiment chitosan charge has minor effect because of high $\mathrm{pH}$ of seawater (6.9-7.2) which neutralize most of the positive charges in chitosan's amino groups. Rasmussen \& Østgaard (2003) suggested that surface energy was the crucial factor to prevent bacterial adhesion to the hydrophilic surface provided by chitosan at conditions of high $\mathrm{pH}$. The anti-algal effect of chitosan was previously reported by Ravi Kumar (2000). However, no anti-algal activity of chitosan was observed by other researchers (Pelletier et al. 2009).

\section{Conclusion}

In this experiment, chitosan solution was used to fabricate coatings characterised by FTIR, SEM and WCA. This chitosan solution was applied as a coating on acrylic plastic and antifouling effect against macro- and micro-fouling organisms was studied. The results of this study proved the effectiveness of chitosan coatings on the settlement inhibition of Bugula neritina compared to the control. The chitosan films also significantly reduced the density of fouling bacteria compared to non-toxic paint and control (no coating) when immersed in a natural seawater environment for two weeks. Those results suggest that chitosan is suitable to be used as coating component in order to prevent marine micro-and macro-fouling.

\section{Acknowledgements}

The authors acknowledge financial support from the Research Council of Oman (TRC, RC/AGR/FISH/16/01) We thank Priyanka Sathe for her assistance in conducting the anti-larval experiments.

\section{References}

Al-Fori M, Dobretsov S, Myint M, Dutta J. 2014. Antifouling properties of zinc oxide nanorod coatings. Biofouling 30 (7): 871-882.

Alisashi A, Aïder M. 2012. Applications of chitosan in the seafood industry and aquaculture: A review. Food and Bioprocess Technology, 5(3): 817-830.

Al-Naamani L, Dobretsov S, Dutta J, Burgess JG. 2017. Chitosan-zinc oxide nanocomposite coatings for the prevention of marine biofouling. Chemosphere 168
408-417.

Benhabiles MS, Salah R, Lounici H, Drouiche N, Goosen MFA, Mameri N. 2012. Antibacterial activity of chitin, chitosan and its oligomers prepared from shrimp shell waste. Food Hydrocolloids 29(1): 48-56.

Bryan PJ, Rittschof D, Qian PY. 1997. Settlement inhibition of bryozoan larvae by bacterial films and aqueous leachates. Bulletin of Marine Sciences 61(3): 849-857.

Cai J, Ye W, Wang X, Lin W, Lin Q, Zhang Q, Wu F. 2016. Preparation of copper-chelate quaternized carboxymethyl chitosan/organic rectorite nanocomposites for algae inhibition. Carbohydrate Polymers 151: $130-134$

Cestari AR, Vieira EF, de Oliveira IA, Bruns RE. 2007. The removal of $\mathrm{Cu}$ (II) and $\mathrm{Co}$ (II) from aqueous solutions using cross-linked chitosan - Evaluation by the factorial design methodology. Journal of Hazardous Materials 143(1): 8-16.

Chatelet C, Damour O, Domard A. 2001. Influence of the degree of acetylation on some biological properties of chitosan films. Biomaterials 22(3): 261-268.

Clare AS, Rittschof D, Gerhart DJ, Maki JS. 1992. Molecular approaches to nontoxic antifouling. Invertebrate Reproduction \& Development 22(1-3): 67-76.

Dobretsov S, Dahms HU, Qian PY. 2006. Inhibition of biofouling by marine microorganisms and their metabolites. Biofouling 22(1): 43-54.

Coma V, Deschamps A, Martial-Gros A. 2003. Bioactive packaging materials from edible chitosan polymer-antimicrobial activity assessment on dairy-related contaminants. Journal of Food Science 68(9): 2788-2792.

Dahms HU, Dobretsov S, Qian, PY. 2004. The effect of bacterial and diatom biofilms on the settlement of the bryozoan Bugula neritina. Journal of Experimental Marine Biology and Ecology 313(1): 191-209.

El-Sawy NM, El-Rehim HAA, Elbarbary AM, Hegazy ESA. 2010. Radiation-induced degradation of chitosan for possible use as a growth promoter in agricultural purposes. Carbohydrate Polymers 79(3): 555-562.

Faimali M, Garaventa F, Terlizzi A, Chiantore M, Cattaneo-Vietti R. 2004. The interplay of substrate nature and biofilm formation in regulating Balanus amphitrite Darwin, 1854 larval settlement. Journal of Experimental Marine Biology and Ecology 306(1): 3750.

Fernandez-Saiz P, Lagaron JM, Ocio MJ. 2009. Optimization of the film-forming and storage conditions of chitosan as an antimicrobial agent. Journal of Agricultural and Food Chemistry 57(8): 3298-3307.

Gall SC, Thompson RC. 2015. The impact of debris on marine life. Marine Pollution Bulletin 92(1): 170-179. 
Goldstein MC, Carson HS, Eriksen M. 2014. Relationship of diversity and habitat area in North Pacific plastic-associated rafting communities. Marine Biology 161(6): 1441-1453.

Goy RC, Britto DD, Assis OB. 2009. A review of the antimicrobial activity of chitosan. Polímeros 19(3): 241247.

Hellio C, Yebra DM. 2009. Advances in marine antifouling coatings and technologies. Woodhead Publishing Series in Metals and Surface Engineering, Elsevier.

Jumaa M, Furkert FH, Müller BW. 2002. A new lipid emulsion formulation with high antimicrobial efficacy using chitosan. European Journal of Pharmaceutics and Biopharmaceutics 53(1): 115-123.

Kong M, Chen XG, Xing K, Park HJ. 2010. Antimicrobial properties of chitosan and mode of action: a state of the art review. International Journal of Food Microbiology 144(1): 51-63.

Krajewska B. 2005. Membrane-based processes performed with use of chitin/chitosan materials. Separation and Purification Technology 41(3): 305-312.

Lam ND, Diep TB. 2015. Comparative study on the antifungal activity of chitosan of various origins tested in different conditions of radiation treatment and culture mediums. Tap Chi Sinh Hoc 25(2): 7-12.

Leceta I, Guerrero P, De la Caba K. 2013. Functional properties of chitosan-based films. Carbohydrate Polymers 93(1): 339-346.

Li HX, Orihuela B, Zhu M, Rittschof D. 2016. Recyclable plastics as substrata for settlement and growth of bryozoans Bugula neritina and barnacles Amphibalanus amphitrite. Environmental Pollution 218: $973-$ 980.

Linneman J, Paulus D, Lim-Fong G, Lopanik NB. 2014. Latitudinal variation of a defensive symbiosis in the Bugula neritina (Bryozoa) sibling species complex. PloS one 9(10): e108783.

Luo Y, Wang Q. 2013. Recent advances of chitosan and its derivatives for novel applications in food science. Journal of Food Processing \& Beverages 1(1): 1-13.

Machul A, Mikołajczyk D, Regiel-Futyra A, Heczko P B, Strus M, Arruebo M, Stochel G. Kyzioł A. 2015. Study on inhibitory activity of chitosan-based materials against biofilm producing Pseudomonas aeruginosa strains. Journal of Biomaterials Applications 30(3): 269-278.

Miller MA. 1946. Toxic effects of copper on attachment and growth of Bugula neritina. The Biological Bulletin 90(2): 122-140.

Muthukrishnan T, Govender A, Dobretsov S, Abed RMM. 2017. Evaluating the reliability of counting bacteria using epifluorescence microscopy. Journal of Marine Science and Engineering 5 (1): 4.
No HK, Park NY, Lee SH, Meyers SP. 2002. Antibacterial activity of chitosan and chitosan oligomers with different molecular weights. International Journal of Food Microbiology 74(1): 65-72.

Park SC, Choi C, Jeong GW, Lee HS, Choi SJ, Kim WS, Nah JW. 2016. Algicidal effects of free-amine water-soluble chitosan to marine harmful algal species. Journal of Industrial and Engineering Chemistry 34: 139-145.

Pelletier E, Bonnet C, Lemarchand K. 2009. Biofouling growth in cold estuarine waters and evaluation of some chitosan and copper anti-fouling paints. International Journal of Molecular Science 10: 3209-3223.

Pitakpoolsil W, Hunsom M. 2014. Treatment of biodiesel wastewater by adsorption with commercial chitosan flakes: parameter optimization and process kinetics. Journal of Environmental Management 133: 284-292.

Price HL, Gohad NV, Mount AS, Wendt DE. 2017. Investigation of larval settlement pathways in the marine bryozoan, Bugula neritina. Journal of Experimental Marine Biology and Ecology 486: 69-76.

Qian PY, Lau SC, Dahms HU, Dobretsov S, Harder T. 2007. Marine biofilms as mediators of colonization by marine macroorganisms: implications for antifouling and aquaculture. Marine Biotechnology 9(4): 399-410.

Rabea, E. I., Badawy, M. E. T., Stevens, C. V., Sagghe, G., \& Steurbaut,W. (2003). Chitosan as antimicrobial agent: Applications and mode of action. Biomacromolecules, 4(6), 1457-1461.

Ramya R, Venkatesan J, Kim SK, Sudha PN. 2012. Biomedical applications of chitosan: an overview. Journal of Biomaterials and Tissue Engineering 2(2): 100111.

Rasmussen K, Østgaard K. 2003. Adhesion of the marine bacterium Pseudomonas sp. NCIMB 2021 to different hydrogel surfaces. Water Research 37(3): 519-524.

Rasmussen K, Willemsen PR, Østgaard K. 2002. Barnacle settlement on hydrogels. Biofouling: 18(3): 177191.

Ravi Kumar MNV. 2000. A review of chitin and chitosan applications. React. Functional Polymers 46: 1-27.

Ryland JS, Bishop JD, De Blauwe H, El Nagar A, Minchin D, Wood CA, Yunnie AL. 2011. Alien species of Bugula (Bryozoa) along the Atlantic coasts of Europe. Aquatic Invasions 6(1): 17-31.

Sekiguchi S, Miura Y, Kaneko H, Nishimura SI, Nishi N, Iwase M, Tokura S. 1994. Molecular weight dependency of antimicrobial activity by chitosan oligomers. In: Nishinari K, Doi E, editors. Food hydrocolloids. Springer, Boston, MA. p. 71-76.

Sudha PN, Gomathi T, Venkatesan J, Kim SK. 2015. Ma- 
rine Biomaterials as Antifouling Agent. In: Kim SK, Editor. Springer Handbook of Marine Biotechnology. Springer, Berlin, Heidelberg. p. 1181-1192.

Wahl M. 1989. Marine epibiosis. I. Fouling and antifouling: some basic aspects. Marine Ecology Progress Series 58: 175-189.

Wang XP, Shen ZQ. 2000. Studies on the effects of copper salts on the separation performance of chitosan membranes. Polymer International 49(11): 14261433.

Yang WJ, Cai T, Neoh KG, Kang ET, Dickinson GH, Teo SLM, Rittschof D. 2011. Biomimetic anchors for antifouling and antibacterial polymer brushes on stainless steel. Langmuir 27(11): 7065-7076.

Zhang M, Helleur R, Zhang Y. 2015. Ion-imprinted chitosan gel beads for selective adsorption of $\mathrm{Ag}+$ from aqueous solutions. Carbohydrate Polymers 130: 206-
212.

Zhou J, Romero G, Rojas E, Ma L, Moya S, Gao C. 2010. Layer by layer chitosan/alginate coatings on poly (lactide-co-glycolide) nanoparticles for antifouling protection and Folic acid binding to achieve selective cell targeting. Journal of Colloid and Interface Science 345(2): 241-247.

Zhou Q, Qiu H, Shan CL, Li B, Ibrahim M, Xie GL Wang YL, Sun GC. 2013. Antibacterial activity of chitosan against the Asian pear pathogenic bacterium Bacillus pumilus. Asian Journal of Chemistry, 25(8), 4337.

Zhao ZP, Wang Z, Wang SC. 2003. Formation, charged characteristic and BSA adsorption behavior of carboxymethyl chitosan/PES composite MF membrane. Journal of Membrane Science 217(1): 151-158. 